\title{
A Mixed Method Research on Peer Assessment
}

\author{
Gokhan Izgar ${ }^{1}$, Ahmet Oguz Akturk² \\ ${ }^{1}$ Department of Curriculum and Instruction,Necmettin Erbakan University, Turkey \\ ${ }^{2}$ Department of Computer Education and Instructional Technology, Necmettin Erbakan University, Turkey
}

\begin{tabular}{l}
\hline Article Info \\
\hline Article history: \\
Received Apr 18, 2018 \\
Revised May 27, 2018 \\
Accepted May 30, 2018 \\
\hline
\end{tabular}

\section{Keyword:}

Mixed method research

Peer assessment

Preservice teachers

\begin{abstract}
This study aimed to investigate the relationship between peer assessment and instructor assessment and make a comparison with views of preservice teachers. The study employed mixed method approach. The quantitative data in this study, in which 27 preservice teachers participated on a voluntary basis, were obtained from scoring rubric whereas qualitative data were obtained from a semi-structured interview form prepared by the researchers. Statistical analyses were conducted to analyze the quantitative data collected within the scope of the study, whereas Pearson Product-Moment Correlation Coefficient was used to analyze the relationship between instructor assessment and peer assessment, and paired samples $t$ test was used to determine the differences between pairwise groups. The qualitative data, on the other hand, were analyzed using the content analysis technique. As a result of the analysis, it was seen that there was a positive and significant correlation between instructor assessment and peer assessment. When the preservice teachers' views were examined, those views rose to prominence stating that making assessments contributed to learning; they grew aware of imperfect knowledge; questioning and critical thinking improved, and fair assessment skills developed. This was interpreted to mean that preservice teachers could distinguish between adequate and inadequate work. However, when the preservice teachers' views concerning their assessments by their peers were examined, the view attracted attention stating that friendship relations and personal problems affected assessment negatively and therefore peers gave low scores. At this point, when the mean scores were examined, it was seen that mean peer scores were higher than instructor mean scores. This was interpreted to mean that some preservice teachers did not have confidence in their peers.
\end{abstract}

Copyright $\left(C_{0} 2018\right.$ Institute of Advanced Engineering and Science. All rights reserved.

\section{Corresponding Author:}

AhmetOguzAkturk,

Department of Computer Education and Instructional Technology,

Necmettin Erbakan University,

TorosMahallesi, ÜniversiteCaddesi, No: 442310 Ereğli/KONYA, Turkey.

Email: aoakturk@konya.edu.tr

\section{INTRODUCTION}

Although peer assessment has been regarded as a new method of assessment in recent years, it is a concept whose existence has been known for years. George Jardine, who was a professor at Glasgow University between 1774 and 1826, referred to the methods and advantages of peer assessment in his studies [1]. Today, peer assessment is frequently referred to especially in constructivist educational practices.

Peer assessment is based on active learning philosophy by virtue of the fact that it is a manifestation of androgogia and social constructivism. In active learning, a learner makes sense of information through their own experiences [2]. Peer assessment is a method of assessment where learners actively participate in assessment of their learning level. Learners learn from one another by receiving and giving feedback in peer assessment. Such activities encourage learning and in this process learners try to realize their own 
learning [2], [3]. Peer feedback may be corroborative, advisory or corrective. Feedback may reduce mistakes and affects learning positively [1]. Peer feedback informs learners of their strengths and weaknesses and indicates the next step they need to take in the learning process. An important condition promoting learning in assessment is that learners participate actively in the process of their being assessed [3].

Peer assessment is a method that enables learners to assess the level, value or quality of a product or to determine performances of other learners of equal status. Equal status can be interpreted as a learner at one's own level, or a colleague or any individual who has received education in that field for a few years. Peer assessment is mostly a form of providing reciprocal feedback among assessors [1]. Learners react differently to feedbacks coming from adults and peers during the process of assessment. While learners perceive feedbacks from adults as authoritarian, they perceive feedbacks from peers as open to negotiation as well as richer feedbacks [1]. When students assess friends' levels of efficiency in their studies, their own critical thinking skills improve. Peer assessment provides teachers with feedback about students' levels of development and proficiency [4].

Peer assessment activities can be implemented in any subject area and at any level. A wide range of products or outputs such as articles, portfolios, oral presentations, test performances etc. can be assessed. Assessors and the assessed can be in the form of pairs or groups. Assessment can be unidirectional or reciprocal and student participation should be ensured in determination of assessment criteria. Objectives of peer assessment may vary. For example, one may want to make cognitive gains, save time or fulfill other objectives [2],[1]. The peer assessment method also helps develop students' assessment skills. A common concern about peer assessment is whether it is as reliable as assessment by teachers [5]. It was concluded in a study conducted by [1] that peer assessment was as reliable as teacher assessment. However, it would be beneficial to give the assessment criteria to students in advance to prevent biased behaviors by students in peer assessment practices [4].

When the relevant literature is reviewed, it is seen that there are numerous studies on peer assessment. Some of these studies arrived at the conclusion that peer assessment increased the quality of learning and provided constructive feedback with respect to learning. These studies also found that peer assessment promoted learning and improvement, improved communicative skills, and students had favorable views concerning this method [5-11]. On the other hand, there are also quantitative studies investigating the relationship between peer assessment and teacher assessment. While a majority of these studies found a statistically significant difference between the results of teacher assessment and peer assessment, others found a high correlation between peer and teacher scores [12-18].

\section{RESEARCH METHOD}

Since quantitative and qualitative methods were used together in this study, it was grounded on the mixed method approach. According to [19], mixed method studies are defined as the use of quantitative and qualitative approaches together in a study. Therefore, the mixed method enables using of multiple data sources when seeking answers to research questions. In this respect, the reason for collecting qualitative data as well as quantitative data in this study is to determine different or similar points of views of students and describe the existing situation in this way.

\subsection{Research Group}

Teddlie\& Yu [20] subsumed samples types in mixed method studies under four major headings. Of these, the convenience sample is the method of selection of participants who are easily accessible and who volunteer to participate in the study. Given this perspective, the present study used the convenience sample and the research group consisted of $273^{\text {rd }}$ grade preservice teachers who participated in the study on a voluntary basis and who were attending the Turkish Teaching Department at the Education Faculty of a state university.

\subsection{Research Procedures}

The practice of peer assessment is based on learners' active participation in the assessment process. This method does not only involve assessment but also enables learners to acquire some skills such as preparing projects, presentation and communication, and implement their own learning. Based on this, the topic of study which the preservice teachers would prepare throughout the semester was planned according to the content of the study. The topic of study which each preservice teacher would prepare was planned making use of the course book that was decided to be taught during the academic year.

The scoring rubric was prepared together with the preservice teachers in the peer assessment application to raise preservice teachers' attendance to a maximum level, prevent biased behaviors and enable preservice teachers to thoroughly know what is expected of them with regard to the study the preservice teachers would prepare. At the same time, this scoring rubric was also going to be used to collect the 
quantitative data of this study and detailed information about it was provided in the data collection tools section.

The Special Teaching Methods II course, which was taught in the Turkish Teaching Division of the Social Sciences Teaching Department at the Education Faculty, was conducted by the course instructor for 4 hours a week for 14 weeks (Spring Semester of the 2016-2017 academic year). During the first four weeks, the course instructor gave basic theoretical information about the course, explained how the peer assessment application would be implemented as well as the work to be done by the preservice teachers. In addition, the preservice teachers' research periods and presentation plans were determined. From the fourth week on, the preservice teachers began to present for 10 weeks to the class the study they prepared. Peer and instructor assessments were made at the end of each presentation between the preservice teachers who conducted the study and the peers and the instructor using the question-answer technique.

The views of the preservice teachers concerning the application were elicited after the term final examination to prevent them from experiencing anxiety. The interviews lasted for about a week.

\subsection{Data Collection Tools}

Scoring rubric was used in the study as the quantitative data collection tool. The scoring rubric was prepared together with the students, taking into consideration the stages suggested by [21]. These stages are listed as:

1. Examination of the scoring rubrics related to the field

2. Listing of performance criteria

3. Determination of performance levels for each criterion

4. Making definitions of performance levels

5. Scoring of the specified levels

The relevant literature was reviewed before passing to the procedure of developing the scoring rubric to be used in the course and best practices were examined. Then, the criteria with respect to the performance expected of the preservice teachers were listed. 10 criteria were determined that were associated with the objectives of the course. Performance levels were defined and definitions of levels were made for each criterion in cooperation with the preservice teachers. A grading scale ranging from excellent to unsuccessful was made in the scoring of specified performance levels. They were as follows; excellent $=4$, successful $=3$, acceptable $=2$, insufficient $=1$, unsuccessful $=0$. The highest score a preservice teacher could receive as a result of the peer and instructor assessments was 40 and the lowest score was 0. Expert opinion was asked in regard to the validity of the scoring rubric, necessary corrections were made and it was given its final form.

"The Semi-Structured Interview Form" was used in the study as the qualitative data collection tool. The interview form prepared by the researchers contained 2 open-ended questions. They were as follows:

a. Your friends presented the daily lesson plan they prepared in this class. You asked your friends questions like a teacher, you criticized or supported them. Express your positive and negative views about this process, assessing the process briefly?

b. You presented your daily lesson plan which you prepared for this course as a preservice teacher. Your friends asked you questions, they criticized or supported you. They assessed you briefly. What are your positive and negative views about this process?

\subsection{Analysis of the Data}

The skewness and kurtosis coefficients of the scale factors were calculated to determine the appropriate statistical techniques that could be used to arrive at results having scientific validity from the data collected within the scope of this study. The values obtained as a result of the calculation are given in Table 1.

Table 1.Descriptive Statistics Related to Instructor and Peer Assessment Scores

\begin{tabular}{lcccccc}
\hline Measurement & $\overline{\mathrm{X}}$ & $\mathrm{SD}$ & Min. & Max. & Skewness & Kurtosis \\
\hline Instructor Assessment & 30.68 & 4.219 & 20 & 37 & -.905 & -.057 \\
Peer Assessment & 33.98 & 3.417 & 20 & 40 & -.897 & .620 \\
\hline
\end{tabular}

When Table 1 is examined, it is seen that the coefficients of skewness and kurtosis calculated for instructor and peer assessment scores were between -1 and +1 , which indicates that the scores received from the factors exhibited normal distribution [22]. As a result of this, it was decided that parametric tests be used on the data obtained. Descriptive statistics were used to analyze the data obtained within the scope of the

IJERE Vol. 7, No. 2, June2018: 118-126 
study; Pearson Product Moment Correlation Coefficient was used to analyze the relationship between instructor assessment and peer assessment; and paired samples t test analysis was used to determine the differences between pairwise groups.

The qualitative data in this study were analyzed using the content analysis technique. The themes were developed based on the questions included in the interview form prepared by the researchers to address the related research questions. Direct quotations were used to be able to reflect the opinions of the preservice teachers with whom interviews were held.

Validity and reliability are two important criteria to assure the legitimacy of the results of a study. In a well-conducted study, the detailed report of the information and how the researchers obtained the presented results is an important criterion for validity [23]. The data collection and data analysis processes were explained in detail in order to establish the validity of the present study. Furthermore, the information obtained from this study was supported with the written statements of the students.

In order to ensure reliability in the analysis of qualitative data, the data obtained from the interview form were encoded separately and thus evaluated. In order to ensure reliability in the analysis of qualitative data, the data obtained from the interview form were encoded separately and thus evaluated. The cases for which the same coding was used were designated as "agreement", whereas the cases for which a different coding was used were designated as "disagreement". As a result of the calculations which were made after the determination of agreement in which the same coding was made and disagreement in which a different coding was made at the end of the analysis, the mean rate of reliability between encodings were found to be $79 \%$. According to [24], if reliability is calculated to be above $70 \%$ for a study, this is sufficient for the study to be considered reliable.

\section{RESULTS AND ANALYSIS}

In this section, it is explained the results of research and at the same time is given the comprehensive discussion. Results can be presented in figures, graphs, tables and others that make the reader understand easily [2], [5]. The discussion can be made in several sub-chapters.

\subsection{The Relationship Between Instructor and Peer Assessments}

Pearson Product Moment Correlation Coefficient was used to analyze the relationship between instructor assessment and peer assessment. The values obtained as a result of the analysis are given in Table 2 .

Table 2. The Relationship between Instructor Assessment and Peer Assessment

\begin{tabular}{lcc}
\hline Variable & \multicolumn{2}{c}{ Peer Assessment } \\
\hline \multirow{2}{*}{ Instructor Assessment } & $-\mathrm{r}-$ & $-\mathrm{p}-$ \\
& $.340^{* *}$ & .000 \\
\hline **. Correlation is significant at the level of 0.01 & (2-tailed).
\end{tabular}

When Table 2 is examined, a positive and significant relationship is observed between instructor assessment and peer assessment. This result indicates that as the instructor assessment score increases, so does the peer assessment score.

\subsection{A Comparison of Instructor and Peer Assessment Scores}

Paired samples $t$ test was used to determine whether the differences between the instructor assessment and peer assessment mean scores were statistically significant. Results of the instructor assessment and peer assessment are given in Table 3.

Table 3. Results of Paired Samplest Test for Comparison of Instructor Assessment and Peer Assessment

\begin{tabular}{lccccc}
\hline Measurement & $\mathrm{N}$ & $\overline{\mathrm{X}}$ & $\mathrm{SD}$ & $\mathrm{t}$ & $\mathrm{p}$ \\
\hline Instructor Assessment & 614 & 30.68 & 4.219 & -18.442 & .000 \\
Peer Assessment & 614 & 33.98 & 3.417 & & \\
\hline
\end{tabular}

When the values given in Table 3 are examined, it is seen that the difference between instructor assessment and peer assessment mean scores is statistically significant $(\mathrm{t}=-18.442 ; \mathrm{p}<0.05)$. While the mean 
of instructor assessment scores is $\bar{X}=30.68$, the mean for peer assessment scores is $\bar{X}=33.98$. These results indicate that peer assessment scores are higher than instructor assessment scores.

\subsection{Preservice Teachers' Opinions About Their Assessment of Their Peers}

Preservice teachers' opinions about their assessment of their peers in the class practices based on the peer assessment method are given in Table 4. As a result of an analysis of the information obtained from the preservice teachers, it is seen that these opinions can be subsumed under 6 themes.

Table 4. Preservice Teachers' Opinions about Their Assessment of Their Peers

\begin{tabular}{lrr}
\hline Theme & $\mathrm{f}(\%$ of Preservice Teachers *) & $\%$ Views \\
\hline Making assessments contributes to learning & $10(37.0)$ & 31.3 \\
It contributes to preservice teachers' feeling themselves in the role & $9(33.3)$ & 28.1 \\
of a teacher and to raising a sense of responsibility & & \\
It helps learning and making a fair assessment & $4(25.9)$ & 21.9 \\
It contributes to critical thinking & $1(3.8)$ & 12.5 \\
It helps one treat tolerantly towards peers & $1(3.7)$ & 3.1 \\
Making assessments makes no contributions to learning & 32 & 3.1 \\
\hline
\end{tabular}

$*$ Total \# of preservice teachers $=27$

For learners to implement their own learning in lessons taught using the peer assessment method, they need to assume the identity of a student who questions and debates through a critical point of view. Learners are expected to question the work done, make comparisons, discuss through questions like why and for what reason, which are focused on thinking, and present their own assessments at the end of this process. When the themes in Table 4 are examined, it is seen that the preservice teachers stated concerning their assessments of their peers that making assessments made the most contribution to learning $(\mathrm{f}=10)$, followed by feeling the role of teacher, developing a sense of responsibility, and learning to make a fair assessment. A few of the preservice teachers' opinions in this regard are:

“...When asking questions, I asked not only to criticize but also to learn. ...studying from a book is not enough to learn. We learn information by heart but cannot use it. During the practice, I tested how much I knew." (PT-7)

"During the assessment process, I saw that what I knew to be true was in fact wrong..." (PT-25)

"I learned to have a critical look at the work done by others. For, this was necessary for me to give fair marks..." (PT-10)

"It helped direct our friends; if they had made a mistake, we corrected it. We exchanged our opinions by asking questions." (PT-20)

“...When I considered myself assessing my friends, I was not fair since I did not know many methods and techniques...So I think that assessing my friends did not contribute anything to me." (PT-9)

Peer assessment is not confined to assessment of a certain product only. It is a learning method by which some skills are also gained. Thus, preservice teachers, who are going to be educationists of the future, are expected to develop assessment skills and a sense of justice and responsibility. At this point, opinions of some preservice teachers are as follows:

"It has contributed a lot to me. My sense of responsibility has improved and I would like to emphasize that I make just decisions in my own way and make assessments in this line..." (PT-21)

"I think I assess fairly just like a teacher... I felt myself in the role of a real teacher... "(PT-25)

"It was good that you involved us in scoring our friends' work. We may consider it a preliminary to be able to make conscientious marking when we become teachers..."(PT-1)

"...I made a point of being objective when I was making my assessments. Its contribution to me was that it helped me be objective and impartial in my assessment." (PT-2)

\subsection{Preservice Teachers' Opinions Concerning Their Assessment by Their Peers}

Preservice teachers' opinions about their assessment by their peers in the class practices based on the peer assessment method are given in Table 5. As a result of an analysis of the information obtained from preservice teachers, it is seen that their opinions can be subsumed under 4 themes.

IJERE Vol. 7, No. 2, June2018: 118-126 
Table 5.Preservice Teachers' Opinions concerning Their Assessment by Their Peers

\begin{tabular}{lcc}
\hline Theme & $\mathrm{f}(\%$ of Preservice Teachers *) & $\%$ Views \\
\hline $\begin{array}{l}\text { One's realization of their incomplete knowledge and reinforcement } \\
\text { of correct information }\end{array}$ & $11(40.7)$ & 34.4 \\
Criticisms or suggestions contribute to learning & $9(33.3)$ & 28.1 \\
$\begin{array}{l}\text { Peers do not make fair assessments; they prioritize personal } \\
\text { problems or friendship }\end{array}$ & $9(33.3)$ & 28.1 \\
Suggestions or criticisms are not at an adequate level & $3(11.1)$ & 9.4 \\
\hline
\end{tabular}

$*$ Total \# of preservice teachers $=27$

Topping [1] states that learners perceive feedbacks from peers in the peer assessment process as feedbacks that are open to negotiation and richer. In addition, during lesson practices, learners can ask each other all the questions in their minds more easily and discuss with one another in a more relaxed manner. When the themes in Table 5 are examined, it is seen that a large majority of the preservice teachers $(\mathrm{f}=20)$ expressed positive opinions about their being assessed by their peers. However, it can be said that a considerable number of preservice teachers $(\mathrm{f}=12)$ had negative opinions of their being assessed by their peers. A few of the preservice teachers' opinions in this regard are as follows:

"...I knew about teaching strategies, methods and techniques as far as I studied them. I better learned the task I prepared thanks to my friends' criticisms." (PT-3)

"...I realized that I had serious shortcomings. It helped me eliminate my shortcomings in this regard. I have total confidence in my friends. The scores they gave are the ones I have deserved. What matters is I should take my lesson from this score." (PT-5)

"... The score may be lower than it normally should have been because I think not everyone in the classroom will be able to act objectively. Anyway, the score does not mean everything. What matters is whether we have learned something. I know that I reinforced what I learned and knew, and corrected incorrect knowledge." (PT-7)

"...My friends noticed the points that escaped my attention. ...I do not think my friends were entirely impartial, all the same." (PT-12)

"...My classmates involved their personal problems in this affair. Or, they gave low grades without even listening to the presentation lest others got higher scores than them."(PT-10)

"...Nobody was assessed objectively. For, they thought that the questions asked were aimed at pushing them." (PT-18)

"Although we had some difficulty in this process, I think we implemented a true learning. I was not troubled by the criticisms because they were not unfair. On the contrary, they made a positive contribution. We found an opportunity to get rid of our shortcomings." (PT-23)

\section{DISCUSSION}

According to the quantitative findings of this study, which aimed to reveal the relationship between peer and instructor assessments and the opinions of preservice teachers as a result of class activities planned in accordance with assessment-based learning, a significant relationship is seen between instructor assessment and peer assessment. That is to say, as the instructor assessment score increases, so does the peer assessment score, and as the instructor assessment score decreases, so does the peer assessment score. In studies conducted by [6], [15] and [17], which support the findings of this study, a high level of correlation was found between peer scores and teacher scores and the means of peer scores turned out to be higher than the means of teacher scores. In another study conducted by [19], it was found that the level of agreement between teachers and students were $31 \%$ and it was concluded that $62 \%$ of the students gave high scores. The finding of this study may be interpreted to mean that preservice teachers were able to act in a way similar to the instructor in the assessment process and distinguish good work from inadequate one. This situation is also supported by the qualitative findings of the study, so much so that when the opinions of the preservice teachers were examined, they stated that making assessments contributed to learning and that they learned to make fair assessments in the process, which indicates that they are indeed able to tell apart efficient work from inefficient work.

Another finding of the study was that there was a statistically significant difference between teacher assessment scores and peer assessment scores and that this difference was in favor of peer assessment scores. In studies conducted by [13] and [16], which seem to support this finding of the study, a statistically significant difference was observed in favor of peers between the assessments scores for instructors and peers. This situation is in contradiction with the qualitative finding of the study; this is so much so that, when the preservice teachers' opinions about their being assessed by their peers are examined, the views that a fair 
assessment was not made; relationships and personal problems negatively affected assessment and therefore peers gave low scores are noteworthy. Therefore, although opinions of some student are negative, when the means of the scores are examined, it is seen that mean peer scores is higher than mean instructor scores. This situation may be interpreted to mean that some students do not trust their peers. In [12]'s study, which supports the findings of this study, it was concluded that teachers were of the opinion that students did not act objectively in peer assessment. Likewise, it was concluded in [18]'s study that close friendly relationships were one of the important factors affecting peer assessment.

Another point is that the most important reason behind the use of the peer assessment method in classes is to contribute to learning. For, making an assessment is a higher order skill. Making an assessment involves knowing the concepts related to the topic, engage in reasoning, making comparisons and arriving at a conclusion. Opinions obtained from the students also support this explanation. For, a large majority of the students stated that making assessments and being assessed by their peers gained them questioning ability, contributed to learning and erroneous knowledge was corrected. It was concluded in studies conducted by [8], [9] and [10], which are among studies that support this result of the study, that most of the students assessed by their peers were happy and self-confident; one-third of the students increased their level of selfconfidence and it was a fruitful classroom activity. Likewise, in studies conducted by [5], [7] and [11], preservice teachers stated that peer assessment raised their awareness of their strengths and weaknesses; and contributed to their knowledge and skills with respect to the teaching profession in terms of understanding themselves and each other. It was also concluded that this method gained them critical, creative and reflective skills; increased interaction and cooperation; improved being open to criticisms; and gained assessment skills.

According to [25], the peer assessment method is not only a procedure involving giving scores but it is also a learning process where some skills are gained. According to the findings of the study, the students stated that in addition to its contribution to learning, peer assessment made one really feel like a teacher, and contributed to making fair assessments and developing a sense of responsibility. Especially in teacher training institutions, some professional teaching skills need to be improved as well as learning of school subjects. Therefore, it is thought that when the peer assessment method is applied in classroom practices, some professional teaching skills can be gained such as using methods related to testing and evaluation, and taking responsibility [4].

On the other hand, another result of the study is that a considerable number of students expressed views about the grades given by their peers rather than the contribution of this method to learning. It was seen among the research findings that some students stated that peers did not make fair assessments; they prioritized personal problems or friendships; peers acted tolerantly towards one another; and making assessments did not make any contribution to learning. This situation can be interpreted to mean that some students did not concentrate on learning in the assessment-based teaching method; instead, they concentrated on the grades given. Therefore, it needs to be specifically emphasized that the essential objective of the peer assessment method employed in classroom practices is to contribute to learning.

\section{CONCLUSION AND SUGGESTIONS}

It can be said based on the opinions of the preservice teachers that in this course, which was grounded on assessment-based learning approach, learners are active and at the center of the classes, classroom practices are based on learning by doing and learning through experience, and the learning experience takes place on the basis of exploring, questioning, criticizing, discussing, making comparisons and drawing conclusions. In addition, given the peer and instructor assessment scores, it can be said that preservice teachers were able to behave in a similar way to the instructor in assessment.

It seems natural that there should be a significant difference between peer and instructor assessment scores according to the results of the study because making assessments is a higher order skill. It is thought that it will be hard, in the acquisition of the assessment-based learning skill, to attain to desired results especially for students with inadequate readiness levels with just a few classroom practices. It may be suggested that so far as it is possible, teaching-learning activities be so structured as to allow such practices in other courses, too.

It is noteworthy that some preservice teachers stated that their peers gave low scores purposely due to certain personal problems although peer assessment mean scores were higher than instructor assessment scores according to the research findings. At this point, it can be suggested that it needs to be internalized by learners that the peer assessment method is implemented to ensure permanent learning rather than just giving grades and that a classroom atmosphere should be based on democratic relationships founded on confidence.

Today, in opposition to the traditional teaching, the importance of methods focused on learning by doing and learning through experience, which are constructivist classroom practices, have further increasedin 
importance. In this context, researchers maybe recommended to conduct studies aimed at eliminating the limitations experienced in the implementation of the peer assessment method.

\section{REFERENCES}

[1] Topping, K. J. (2009). Peer assessment. Theory Into Practice, 48(1), 20-27.

[2] Falchikov, N., \& Goldfinch, J. (2000). Student peer assessment in higher education: A meta-analysis comparing peer and teacher marks. Review of Educational Research, 70(3), 287-322.

[3] vanGennip, N. A., Segers, M. S., \&Tillema, H. H. (2010). Peer assessment as a collaborative learning activity: The role of interpersonal variables and conceptions. Learning and Instruction, 20(4), 280-290.

[4] Ministry of National Education (MoNE). (2006). Temel eğitime destek projesi: Öğretmenlik mesleği genel yeterlikleri. Retrieved January 25, 2018, from http:/oygm.meb.gov.tr/www/ogretmenlik-meslegi-genelyeterlikleri/icerik/39

[5] Koç, C. (2011). Sınıf öğretmeni adaylarının öğretmenlik uygulamasında akran değerlendirmeye ilişkin görüşleri. Kuram ve Uygulamada Ĕ̈itim Bilimleri Dergisi, 11(4), 1965-1989.

[6] Bay, E. (2011). Öğretmen adaylarının akran değerlendirmeye ilişkin görüşleri. Gaziantep Üniversitesi Sosyal Bilimler Dergisi, 10(2), 909-925.

[7] Biri, H. (2014). Akran değerlendirme yönteminin öğretmen eğitimine katkısı. Yayınlanmamış Yüksek Lisans Tezi. Trabzon: Karadeniz Teknik Üniversitesi.

[8] Bozkurt, E., \& Demir, R. (2012). Peer assessment through students opinions: A case study. Ilkogretim Online, 11(4), 966-978.

[9] Dochy, F. J. R. C., Segers, M., \& Sluijsmans, D. (1999). The use of self-, peer and co-assessment in higher education: A review. Studies in Higher Education, 24(3), 331-350.

[10] Hamzaday1, E. (2015). Yabancilara Türkçe öğretiminde C1 düzeyinde yazılı akran geribildirimlerine ilişkin görünümler. Zeitschrift für die Welt der Türken/Journal of World of Turks, 7(2), 287-298.

[11] Özan, S. (2008). Öz ve akran değerlendirmenin temel iletişim becerileri üzerindeki etkileri. Yayınlanmamış Doktora Tezi. İzmir: Dokuz Eylül Üniversitesi.

[12] Gelbal, S., \& Kelecioğlu, H. (2007). Öğretmenlerin ölçme ve değerlendirme yöntemleri hakkındaki yeterlik algıları ve karşılaştıkları sorunlar. Hacettepe Üniversitesi Ĕ̈itim Fakültesi Dergisi, 33, 135-145.

[13] Kwan, K. P., \& Leung, R. W. (1996). Tutor versus peer group assessment of student performance in a simulation training exercise. Assessment \& Evaluation in Higher Education, 21(3), 205-214.

[14] Orsmond, P., Merry, S., \& Reiling, K. (1996). The importance of marking criteria in the use of peer assessment. Assessment \& Evaluation in Higher Education, 21(3), 239-250.

[15] Özdemir, O., \& Erdem, D. (2017). The effect of friendships to peer assessment of presentation skills. Turkish Journal of Educational Studies, 4(1) 21-40.

[16] Taşdemir, M. (2014). Kendini değerlendirme, akran değerlendirme ve öğretmen değerlendirmenin yazıllı sınav sonuçlarına etkisi ve başarı yordayıcılığı. Turkish Studies-International Periodical for The Languages, Literature and History of Turkish or Turkic, 9(5), 1911-1929.

[17] Uysal, K. (2008). Öğrencilerin ölçme değerlendirme sürecine katılmasl: Akran değerlendirme ve öz değerlendirme. Yayınlanmamış Yüksek Lisans Tezi. Bolu: Abant İzzet Baysal Üniversitesi.

[18] Yalmancı, S. G. (2016). Mikroöğretim uygulamalarında akran değerlendirmelerini etkileyen niteliklerin belirlenmesi. Kastamonu Eğitim Dergisi, 24(4), 2005-2020.

[19] Johnson, R. B., \& Onwuegbuzie, A. J. (2004). Mixed methods research: A research paradigm whose time has come. Educational Researcher, 33(7), 14-26.

[20] Teddlie, C., \& Yu, F. (2007). Mixed methods sampling: A typology with examples. Journal of Mixed Methods Research, 1(1), 77-100.

[21] Andrade, H. G. (2000). Using rubrics to promote thinking and learning. Educational Leadership, 57(5), 13-19

[22] Huck, S. W. (2012). Reading statistics and research (6th ed.). Boston, MA: Pearson.

[23] Yıldırım, A., \& Şimşek, H. (2006). Sosyal bilimlerde nitel araştirma yöntemleri (6. Bask1). Ankara: Seçkin Yayıncılık.

[24] Miles, M. B., \& Huberman, A.M. (1994). Qualitative data analysis: An expanded sourcebook (2nd Edition). Calif: SAGE Publications.

[25] Somervell, H. (1993). Issues in assessment, enterprise and higher education: the case for self-, peer- and collaborative learning. Assessment and Evaluation in Higher Education, 18, 221-233.

\section{BIOGRAPHIES OF AUTHORS}

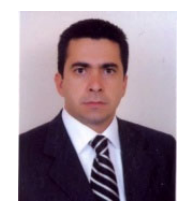

GokhanIzgar is currently serves as an assistant professor at a state university in Turkey. He completed his doctoral dissertation in the field of curriculum and instruction in 2013. His research interests include values education, curriculum development and instructional methods. 
AhmetOguzAkturk is chair and associate professor in the Department of Computer Education
and Instructional Technology at Necmettin Erbakan University (Turkey). His research and teaching focus on appropriate uses of instructional technologies and learning strategies.

IJERE Vol. 7, No. 2, June2018 : 118-126 